\title{
LAS NUEVAS CENTRALIDADES URBANAS EN MONTERÍA, COLOMBIA
}

\author{
Jhon Pinedo López, Universidad Cooperativa de Colombia \\ Carmen Lora Ochoa, Universidad Cooperativa de Colombia \\ Blanca Cecilia Acevedo, Estudiante de Administración de Empresas, UCC, Montería \\ jhon.pinedol@campusucc.edu.co, carmen.lora@campusucc.edu.co
}

\section{RESUMEN}

El punto de partida de esta investigación es el surgimiento de nuevas centralidades urbanas en la ciudad de Montería, que permitieron la desconcentración de algunas funciones y la descentralización de actividades económicas, las cuales eran ofertadas exclusivamente desde el centro tradicional. El objetivo central es determinar su impacto socioeconómico y sus efectos sobre los usos del suelo y morfología urbana de la ciudad. La hipótesis central es que el centro tradicional perdió la supremacía sobre la oferta de servicios de alimentación, financieros y recreación, ante las nuevas centralidades urbanas. El trabajo concluye que las nuevas centralidades son una alternativa de empleo importante, en esta ciudad, brindan mayor seguridad que el centro, e impactan significativamente la morfología urbana.

Palabras claves: centralidades urbanas - impacto socioeconómico - equipamientos urbanos.

\section{ABSTRACT}

The starting point of this research is the emergence of new urban centralities in the city of Monteria, which allowed the deconcentration of some functions and the decentralization of economic activities, which were offered exclusively from the traditional center. The main objective is to determine its socioeconomic impact and its effects on the urban land uses and morphology of the city. The central hypothesis is that the traditional center lost the supremacy over the supply of food, financial and recreation services, before the new urban centralities. The work concludes that the new centralities are an important employment alternative, in this city, they provide greater security than the center, and significantly impact the urban morphology.

Key words: urban centralities - socioeconomic impact - urban facilities. 